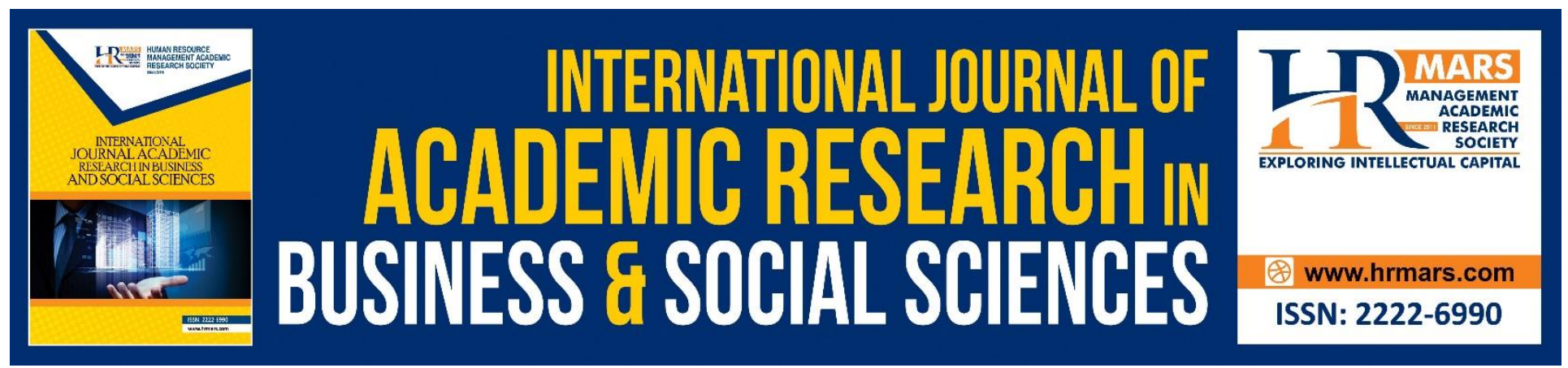

\title{
Description of Manuscripts of Kitab Al- Kifayah in Library Collection in Malaysia
}

Zurita Mohd Yusoff, Abdul Karim Ali, Engku Ahmad Zaki Engku Alwi, Najihah Abd Wahid \& Syed Mohd Hafiz bin Syed Omar

To Link this Article: http://dx.doi.org/10.6007/IJARBSS/v10-i10/7933 DOI:10.6007/IJARBSS/v10-i10/7933

Received: 20 August 2020, Revised: 11 September 2020, Accepted: 25 September 2020

Published Online: 19 October 2020

In-Text Citation: (Yusoff, et al, 2020)

To Cite this Article: Yusoff, Z. M., Ali, A. K., Alwi, E. A. Z. E., Abd Wahid, N., \& Omar, S. M. H. B. S. (2020). Description of Manuscripts of Kitab Al- Kifayah in Library Collection in Malaysia. International Journal of Academic Research in Business and Social Sciences. 10(10), 208-216.

Copyright: (C) 2020 The Author(s)

Published by Human Resource Management Academic Research Society (www.hrmars.com)

This article is published under the Creative Commons Attribution (CC BY 4.0) license. Anyone may reproduce, distribute, translate and create derivative works of this article (for both commercial and non-commercial purposes), subject to full attribution to the original publication and authors. The full terms of this license may be seen at: http://creativecommons.org/licences/by/4.0/legalcode

Vol. 10, No. 10, 2020, Pg. 208 - 216

http://hrmars.com/index.php/pages/detail/IJARBSS

JOURNAL HOMEPAGE

Full Terms \& Conditions of access and use can be found at http://hrmars.com/index.php/pages/detail/publication-ethics 


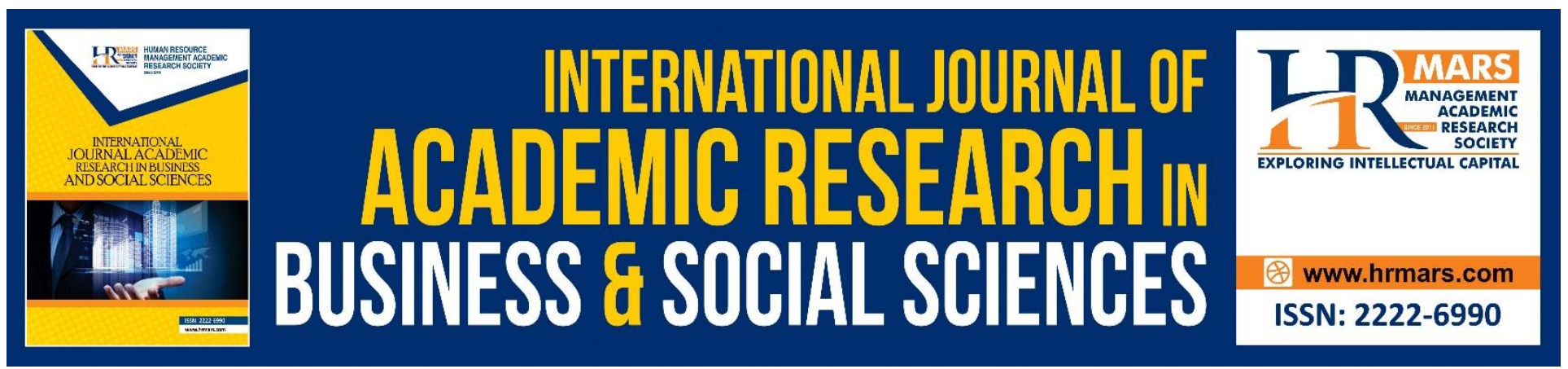

\title{
Description of Manuscripts of Kitab Al- Kifayah in Library Collection in Malaysia
}

\author{
Zurita Mohd Yusoff ${ }^{1}$, Abdul Karim Ali², Engku Ahmad Zaki Engku \\ Alwi ${ }^{1}$, Najihah Abd Wahid ${ }^{1} \&$ Syed Mohd Hafiz bin Syed Omar ${ }^{1}$ \\ ${ }^{1}$ Universiti Sultan Zainal Abidin, Malaysia, ${ }^{2}$ Universiti Malaya, Malaysia \\ Email: zurita@unisza.edu.my
}

\begin{abstract}
The study of Malay manuscripts with Islamic theme must be intensified to explore the thoughts of past scholars. One of the books written by scholars in the 17th century is written by Sheikh Abdul Malik bin Abdullah. The book is recognized as one of the first books of jurisprudence in Malaya written by local scholars. Kitab al- Kifayah has never been printed and is not available in our country's market or abroad. Therefore, this article aims to introduce the author's background, the background of this book and its storage location in libraries in Malaysia. In addition, a complete description of the manuscripts that have been found by the researcher is also explained in this article. The result of this writing found that Sheikh Abdul Malik is a scholar in Terengganu who was very helpful in developing Islam in Terengganu. He founded the school system and write short papers for the purpose of teaching religion in the school as well as a reference for Muslims in Malaya then. A total of 4 copies of Kitab al- Kifayah have been found by the author in two libraries in Malaysia and descriptions for each copy have been made. It is hoped that this description will be of great benefit to researchers in the field of manuscripts as well as the Muslim community in Malaysia.
\end{abstract}

Keywords: Manuscripts, Kitab al-Kifayah, Library Collection, Shaykh Abdul Malik bin Abdullah, Tok Pulau Manis.

\section{Introduction}

Islam has been found having its root in the Malay Archipelago since 7AD with the emigration of Arabs to Java. Islam is becoming more popular in the Malay Archipelago with the intensive efforts by Islamic scholars, both locals and internationals who came from cities such as Baghdad, Egypt, Yemen and Saudi Arabia. These Islamic scholars not only preach orally, but also produced writings that encompass wide-ranging fields of Islamic knowledge (Hasanulddin, 2017). Figh was one of the important fields to be learned and practiced by Muslims. Since the coming of Islam during the 17th century, classical figh writings in Malay were hard to come by and making it hard for the Malays to acquire religious-based writings in their native language. Apart from the lectures that were given by Islamic scholars at that time, Muslims need religious books in Malay as reference points. In dealing 
INTERNATIONAL JOURNAL OF ACADEMIC RESEARCH IN BUSINESS AND SOCIAL SCIENCES Vol. 10, No. 10, 2020, E-ISSN: 2222-6990 @ 2020 HRMARS

with the shortage of religious references in Malay, Tok Pulau Manis has produced his writings in Malay. His book, Kitab al-Kifayah is a book of jurisprudence written in Jawi and was an important reference for Muslims at that time, especially in Terengganu. However, this book has never been printed or published and is not known by the society today. This study is an attempt track the manuscripts of Kitab al-Kifayah kept in the library collection in Malaysia in order to introduce this book to the Muslim community in Malaysia.

\section{Research Method}

Data collection is conducted through the method of document analysis that focuses on the manuscript of Kitab al-Kifayah written by Sheikh Abdul Malik. Other books such as the authoritative books in the jurisprudence of the Shafie sect are also analysed by the author. Interviews with his descendants were also conducted to complete data collection on his biography. The data obtained were analysed using content analysis method.

\section{The Biography of Sheikh Abdul Malik bin Abdullah}

Sharif Muhammad al-Baghdadi or his full name Sharif Muhammad bin Abdullah was a nobleman and also a preacher from Baghdad who had migrated to Mecca. With the intention of developing Islam, he later migrated to Acheh and he then migrated to Terengganu. Eventually, he settled in a village near an island in Kampung Batu Belah, Mukim Jenagor, Ulu Terengganu (Ismail, 2012) and eventually died in this village (Shafie, 1984). His son, Abdul Qahhar, is the grandfather of the figure discussed in this article, namely Sheikh Abdul Malik.

Sheikh Abdul Malik bin Abdullah was born in 1650M in Terengganu. He is a Terengganu-born scholar who is a descendant of a preacher from Baghdad. He is also known by several other titles, namely Dato' Pulau Manis, Tok Syeikh Pulau Manis, Tuan Pulau Manis and Sharif Abdul Malik (Ismail, 2012). According to the birth and death records found at his tomb in Kampung Pulau Manis, Kuala Terenggganu, Sheikh Abdul Malik was born in 1089H / 1678M and died in 1149H / 1736M (A visit to Tok Pulau Manis Tomb, 2018). These recorded dates indicate that Sheikh Abdul Malik had died at the age of 58 years.

However, there are some facts that show Sheikh Abdul Malik was born earlier than the date recorded above. In a book of his writings, there is a note that he once studied with a famous Mecca scholar, Sheikh Ibrahim al-Kurani who lived between the years 1025H / 1661M-1101H / 1690M. According to Shafie (1977), if it is said that he was born in 1690M, then his age when his teacher died was only 12 years. In the researcher's view, it is unreasonable at such a young age that he had studied for several years in Mecca and Acheh. The stories told orally from the heirs of his lineage and some other facts presented by previous researchers also reinforce the fact that Tok Pulau Manis was born earlier than the date recorded in his tomb (Shafie, 1977; Ibrahim, 2011; Saleh, 1983).

The date of death of Sheikh Abdul Malik recorded on his tomb is reasonable and not disputed by any party that is in the year $1149 \mathrm{H} / 1736 \mathrm{M}$. He died at the age of about 86 years. This fact corresponds to one piece of information which mentions that the last stage of his life, he was a man of advanced age (M.C. ff. Sheppard, 1949: 11). Oral stories from his descendants also mention that Sheikh Abdul Malik died when he was quite old (Shafie, 1984).

Many descendants of Sheikh Abdul Malik were recognized living in Kampung Pulau Manis, Kuala Terengganu and some also settled in Pasir Mas District, Kelantan. This is because there is a grandson 
INTERNATIONAL JOURNAL OF ACADEMIC RESEARCH IN BUSINESS AND SOCIAL SCIENCES Vol. 10, No. 10, 2020, E-ISSN: 2222-6990 @ 2020 HRMARS

of Sheikh Abdul Malik named Lebai Hasan who migrated to the state of Kelantan. (Interview with Haji Ismail bin Che 'Daud on 27 March 2019 and Haji Adam Shukri bin Haji Abdullah on 5 July 2019).

Sheikh Abdul Malik was educated in Acheh around 1670M. He is known as a great and prominent student to Sheikh Abdul Rauf Singkel (Azra, 1994). Evidence for his adventure to Acheh is on the book he copied by hand titled Tafsiran Baidawi and written in Malay by Sheikh Abdul Rauf Singkel (Shafie, 1989).

Sheikh Abdul Malik migrated to Mecca around the 1680s when he was in his 30s. He was among the earliest of Malay people studying in Mecca. He eventually returned home to make a very significant contribution as well as other scholars such as Muhammad Arsyad al-Banjari, Nawawi al-Bantani and Sheikh Daud al-Fatani (Redzuan, 1998; Hafey etal., 2019).

Among the three fields of knowledge, namely aqeedah, tasawuf and fiqh, Sheikh Abdul Malik is very interested in the study of tasawuf. The second field of study that was given attention by Sheikh Abdul Malik was jurisprudence. His main teacher was Sheikh Ibrahim al-Kurani. Based on his books, there are many books of jurisprudence were refered by him such as Daw al-Shama'ah by Sheikh Jalaluddin al-Suyuti, Munyah Ahl al-Wara' by Sheikh Ahmad al-Qusaishi, Minhaj al-Talibin by Imam Nawawi, Tatimmah by Ibn Matuli, al-Hawi by al-Mawardi and Nihayah by Imam al-Ramli (Shafie, 1985).

In the field of Usuluddin, Sheikh Abdul Malik has chosen the approach of Imam al-Ash'ari who is the general follower of al-Sunnah wa al-Jamaah in the Islamic world. This approach has also been followed by the leaders of the Tariqat Shadhiliyyah such as Abu al-Hassan al-Shadhili and Abu al'Abbas al-Mursi (Shafie, 1989).

At the age of about 40, Sheikh Abdul Malik left Mecca and returned to his hometown. His return to his homeland was associated with his grief over the death of his teacher, Sheikh Ibrahim al-Kurani in $1101 \mathrm{H} / 1690 \mathrm{M}$. This is because he returned to his homeland after a few days Sheikh Ibrahim alKurani died.

Before the authors proceed with the focus of examining the local examples as well as the influences in Kitab al-Kifayah, we will begin with the biography of SAMA. This section will discuss two main aspects of his life - his birth and educational background.

\section{Background of Kitab al-Kifayah}

The second prominent book written by Sheikh Abdul Malik is Kitab al-Kifayah. This book talks about usuluddin and figh. It talks about questions of faith and the laws of jurisprudence such as taharah, prayer, fasting, zakat, animals that are halal and haram to eat as well as the management of the dead (Abdul-Malik, t.t). Kitab al-Kifayah was written with the aim of being used as teaching material by Tok Pulau Manis for the local community. However, this book has never been printed and has not been found by the author except for two copies stored in the National Library of Malaysia and two more copies in the Malaysian Museum of Islamic Art.

The word "Kifayah" comes from the Arabic word meaning 'sufficient'. With this, it can be concluded that the word Kifayah for the title of this book carries the meaning of religious knowledge that is very important, sufficient and as the basis for a Muslim. This means that Kitab al-Kifayah is a book that contains a complete discussion about the basic knowledge that a Muslim must know or also referred to as fardhu ain. From the study of the four manuscripts of the Kitab al-Kifayah found by the researcher, none of the manuscripts state the original date of Sheikh Abdul Malik composing this Kitab al-Kifayah. However, according to Ismail Che Daud (2012), this Kitab al-Kifayah was completed on Thursday 25 Syawal $1138 \mathrm{H}$ equivalent to 27 th June $1726 \mathrm{M}$. 
INTERNATIONAL JOURNAL OF ACADEMIC RESEARCH IN BUSINESS AND SOCIAL SCIENCES Vol. 10, No. 10, 2020, E-ISSN: 2222-6990 @ 2020 HRMARS

As one from a collection of the oldest jurisprudence books written in Terengganu and among the oldest jurisprudence book in the Malay Peninsula after Kitab Sirat al-Mustaqim (Zurita, 2014), researchers thought Kitab al-Kifayah was written with the aim to spread the basis of religious knowledge either from the aspect of monotheism and also jurisprudence to society at that time. Given the knowledge of Islam among the public was very limited and Sheikh Abdul Malik was one of the earliest Malay people studied in Mecca (Redzuan, 1998), undoubtedly, Kitab al-Kifayah gains the attention of the people of Terengganu during that time and play a great role in spreading Islamic knowledge.

In the late 17th century and early 18th century, religious books written in languages other than English, particularly discussing jurisprudence is also very limited fiqh (Shafie, 1985). The book of jurisprudence in his time is only a book written by the scholars of Acheh and the book that is considered the most authoritative until the middle of the 19th century is the book written by Sheikh Nur al-Din al-Raniri which is the Kitab Sirat al-Mustaqim (1054H / 1664M) (Kadir , 1996). As a result of this research, it can be observed that there are no other scholars in Terengganu or in other states that produced the book of jurisprudence at that time other than Sheikh Abdul Malik who wrote the Kitab al-Kifayah, Risalah al-Naql and Risalah Kayfiyyah al-Niyyah.

The second most important jurisprudence book in the Malay world after Sirat al-Mustaqim is Kitab Mir'at al-Tullab li Ma'rifah al-Shari'ah al-Malik al-Wahhab authored by Sheikh Abdul Ra' uf Fansuri (1024H / 1615M-1105H / 1693M) (Jamalluddin \& Karim, 2009). Next, Kitab Sabil al-Muhtadin by Sheikh Muhammad Arshad al-Banjari appeared in 1195H / 1779M (Kadir, 1996). In the period between the emergence of Kitab Mir'at al-Tullab li Ma'rifah al-Shari'ah al-Malik al-Wahhab and Kitab Sabil al-Muhtadin, Kitab al-Kifayah was born. The birth of the books of jurisprudence written by Tok Pulau Manis during the visits was to fill the lack of reference materials in Malay language, particularly in the field of jurisprudence for the community at the time.

Apart from that, Kitab al-Kifayah is also composed as a basic text or part of the syllabus for students who study at the school founded by Sheikh Abdul Malik bin Abdullah himself. This has been stated by Shafie Abu Bakar in his study:

"This book was written for use in teaching at educational institutions founded by the scholar (Tok Pulau Manis) and religious guidance of the local community." (Shafie, 1985)

Kitab al-Kifayah includes discussions from the aspect of faith and also fiqh. However, the discussion on faith is only $30 \%$ of the entire content of the book, while the other $70 \%$ includes the discussion on jurisprudence. The chapters in this book can be divided into 12 chapters or also known as kitab, namely the Kitab of the Pillars of Faith, the Kitab of the Pillars of Islam, the Kitab of Types of Jurisprudence Laws on Human Actions and Things That Cause Infidelity, Kitab of Purification, Kitab of Prayer, Kitab of Funeral, Kitab of Zakat, Kitab of Fasting, Kitab of Sacrifice, Kitab of Akikah, Kitab of Slaughtering and Kitab of Food (Malik. A, tt).

From the list of chapters above, it is clear that Sheikh Abdul Malik began his discussion by emphasizing on the faith of a Muslim first. He had tried to instill a strong faith in the community at that time by elaborating on the question of saying syahadah as well as things that could invalidate it. After discussing it, then the author begins the discussion on the science of jurisprudence which is preceded by the title of the types of jurisprudence laws on human actions. 
INTERNATIONAL JOURNAL OF ACADEMIC RESEARCH IN BUSINESS AND SOCIAL SCIENCES Vol. 10, No. 10, 2020, E-ISSN: 2222-6990 @ 2020 HRMARS

Kitab al-Kifayah has actually been written with reference to several books that are muktabar in Mazhab Syafie. The main reference book is Tuhfat al-Muhtaj Bisyarh al-Minhaj written by Sheikh alIslam Shihab al-Din Abu al-'Abbas Ahmad bin Muhammad bin 'Ali bin Hajar al-Haytami, an Islamic Jurisprudence scholar from Egypt. Kitab Tuhfat has been considered as a great work in the field of jurisprudence and has a high position among Shafi'iyyah scholars. In addition, Sheikh Abdul Malik also refers to the Kitab Minhaj al-Talibin Wa 'Umdah al-Muftin composed by Muhyi al-Din Abu Zakariyya Yahya bin Sharf bin Murri al-Hazami al-Shafi'i or better known as Imam al-Nawawi (Zurita, 2014).

Another scholar mentioned by the author in this Kitab al-Kifayah is Imam al-Ruyani. Based on this research on the books written by Imam al-Ruyani, there is a large work of jurisprudence and covers various chapters in the field of jurisprudence, namely Bahr al-Madhhab fi Furu 'Madhhab al-Imam alShafi'i.

Apart from the three books above, there are also other books referred to by the author, but not recorded in the text. Among the books found to have the same facts as some of Kitab al-Kifayah texts are Fath al-Wahhab Bi Syarh Manhaj al-Tullab by Imam Abu Zakariyya al-Ansari, Sharh al-Waraqat Li Imam al-Haramain al-Juwaini by Imam Taj al -Din al-Farazi, Mughni al-Muhtaj Ila Ma'rifah Ma'ani Alfaz al-Minhaj by Imam Shams al-Din al-Khatib al-Sharbini and Al-Mustasfa Min 'Ilm al-Usul by Imam alGhazali (Zurita, 2014)

\section{Description of Manuscripts of Kitab al-Kifayah in Library Collection in Malaysia}

After conducting a search to obtain as many copies for the manuscript of Kitab al-Kifayah, the researcher has found four copies that are all stored in the library collection in Malaysia. In addition, the researcher is also trying to obtain a copy that may be kept in the personal collection of the manuscript collector or his family members, but until now the researcher has not managed to find it. The descriptions of the four manuscripts found are as follows:

\section{i- $\quad$ MSS 517}

This manuscript measures $20.8 \mathrm{~cm} \times 17.5 \mathrm{~cm}$ and contains 120 pages or 60 sheets (folio). Each page contains 21 lines. This copy is clearly acknowledged by the copyist as a book written by Sheikh Abdul Malik or Tok Pulau Manis. It was copied by Abdullah Latif bin Almarhum Abdul Mu'min who is also known as Tok Kelaba and was completed on 16 October 1880M / 13 Zulkaedah 1297H in Kampung Beris, Kelaba State. The ink used is black, rubrics for certain words (International Malay Manuscript Exhibition Catalog, 1995). This manuscript has a complete page and its writing is clearer as well as making it easier for the reader to read it. This manuscript is now kept at the Centre for Malay Manuscripts, National Library of Malaysia in Kuala Lumpur.

\section{ii- MSS 1897}

This copy contains 125 pages (folio) which is 250 pages. Each page contains only 15 lines. The MSS 1897 copies are also stored in the Centre for Malay Manuscript, National Library of Malaysia in Kuala Lumpur. In this manuscript, there is no record that shows it is the work of Sheikh Abdul Malik. On the other hand, on the last page is mentioned the name of the author is Imam Shafie. Researchers observed that the copyist of this manuscript recorded it as the work of Imam Shafie because most of the laws found in this book are taken from authoritative books in the Shafie sect. On the last page 
INTERNATIONAL JOURNAL OF ACADEMIC RESEARCH IN BUSINESS AND SOCIAL SCIENCES

Vol. 10, No. 10, 2020, E-ISSN: 2222-6990 @ 2020 HRMARS

there is also a note that this manuscript was completed on Thursday 2 Safar $1180 \mathrm{H} / 8$ July $1766 \mathrm{M}$. This means that this second copy was written 117 years earlier than the first. However, unlike the first copy, the name of the copyist is not listed on this copy. Some pages from this manuscript were found to be incomplete as they had been torn and had gone through a process of conservation from the original condition which was too worn out. The original manuscript is a collection of the late Haji Wan Mohd Saghir bin Abdullah and was found in May 1993 in Kampung Kepala Bukit Senggora and eventually handed over to the Centre for Malay Manuscript, National Library of Malaysia.

iii- $\quad$ IAMM 1998.1.179 (Abdul Malik,t.t.)

This third copy uses yellow laid European paper and has a horizontal line. It contains 61 pages and each page contains 27 lines. Each sheet has a shadow or watermark. This copy is now kept in the Library of the Islamic Arts Museum Malaysia, in Kuala Lumpur. Each page of this manuscript is also found to have gone through a process of tissue repair. Many of the pages have been lost and the existing pages are only 55\%, which is starting from the chapter on the two Sunnah Eid Prayer. Inks used in black and rubricated in red for specific Arabic and Malay word. The name of the author and copyist is not available on this page. Due to the fact that the number of pages available is only $55 \%$ of the total content of the book, it is very likely that the author's name is written on the lost introduction page. In terms of the date of writing or copying, this manuscript only contains the day and month of the end of Kitab al-Kifayah, which is on the Monday of the month of Zulkaedah. The date and year of writing are also not recorded in this manuscript.

iv- IAMM 1998.1.108

The fourth copy found by the researcher is also kept in the Library of the Islamic Arts Museum, Kuala Lumpur. This manuscript was successfully found after five years the researcher found the three manuscripts above. This is because the fourth copy is not catalogued with the name "Kitab alKifayah", instead it is catalogued with the name "Kitab Fiqh" only. This manuscript numbered 1998.1.108 contains two works, namely Kitab al-Kifayah and Risalah Kayfiyyah al-Niyyah which are compiled consequently. This manuscript is incomplete and the page explaining the name of Kitab alKifayah is also most likely missing. This is because the first page of this manuscript continues to mention the law of ablution whether it is valid or not if there is impurity under the long tip of the nail. The same explanation is on page 45 in the first copy of Kitab al-Kifayah (MSS 517) and page 70 in the second copy. The last page of this fourth manuscript of Kitab al-Kifayah continues with Risalah Kayfiyyah al-Niyyah and these two books are only separated by the word basmalah. On this fourth manuscript, no date of writing or copying was recorded.

\section{Other Manuscripts}

Apart from the three manuscripts that have been found by the researcher, there are two other manuscripts whose information is only obtained, but the manuscript has not been found by the researcher until now, namely:

i- Manuscript A (Abdul Malik, t.t.)

This copy measures $21.3 \mathrm{~cm} \times 16.6 \mathrm{~cm}$ and contains 130 pages. It was completely copied on Thursday night, at $9.00 \mathrm{pm}$ on 25 Syawal $1138 \mathrm{H}$ while the author was still alive. However, the name of the copyist of this manuscript is not mentioned. On the start page there are the following statements:

"This book is said by the Kifayah people whose name is from the arrangement of Datuk Pulau Manis which is prominent for its people". (Shafie, 1977) 
ii- Manuscript B ( Abdul Malik, t.t.)

This copy measures $20.7 \mathrm{~cm} \times 17 \mathrm{~cm}$ and contains 152 pages. The text used is found to be slightly larger than copy A, making it thicker than copy A. In this manuscript, no description of the author's name is recorded on the start page. However, on the last page of this copy, there is information on the author's name, copyist name, owner name and also the date of copying:

"Indeed, this Kifayah, written by Haji Abdul Malik, has been completed. The owner is Mariam binti Haji Ahmad, the author is a humble faqir who admits to sin and taqsir is Ali bin Qadi Haji Muhammad Salih Patani who later lived in Terengganu. May Allah forgive him, both his parents, his teachers and for Muslims, believers whether they are alive or dead. Blessings and peace be upon Sayyidina wa Mawlana Muhammad, his family and his friends and all praise is up to God Almighty of the worlds. Year 1282."

Both copies, A and B, were not found by the researcher and were not in the previous researcher's possession. As a result of the researcher's interview with the previous researcher, he said that the manuscripts are not known where the current storage is and may be in the storage of the heirs or the descendants of Sheikh Abdul Malik bin Abdullah. This is because the study he conducted is 33 years old and it is possible that no one manages the manuscripts stored in musolla and school known as the Institution of Sheikh Abdul Malik bin Abdullah.

\section{Conclusion}

Past Malay scholar such as Sheikh Abdul Malik has contributed so much to spread the teachings of Islam in Terengganu. One of his great contributions was to produce works of fiqh. His work in the field of Jurisprudence, Kitab al-Kifayah has become the guide for the Muslim community, especially in Terengganu and Malay Peninsula at the time. The book contains a discussion about faith and jurisprudence is considered to be the basic book for local people when it was already facing a shortage of reference materials in Malay language. It is not only a reference for the locals, but also a reference for residents outside Terengganu to Patani. It is also written in accordance with the community holding the average practicing Shafi'e sect and discussing many aspects of worship as a basic knowledge for a Muslim. The description of the four manuscripts of Kitab al-Kifayah that has been made in this writing based on direct reference to the manuscript as well as the existing description is expected to make it easier for other researchers and the general public to understand this book.

\section{Acknowledgment}

The authors would like to record our appreciation to Universiti Sultan Zainal Abidin (UniSZA), Terengganu for the University's Research Grant Fund (DPU) to our research project entitled "Pengaruh Unsur Semasa dan Setempat dalam Karya-karya Fekah Karangan Tok Pulau Manis." This article is an output of the grant (UniSZA/2017/DPU/30). 
INTERNATIONAL JOURNAL OF ACADEMIC RESEARCH IN BUSINESS AND SOCIAL SCIENCES

Vol. 10, No. 10, 2020, E-ISSN: 2222-6990 @ 2020 HRMARS

\section{Corresponding Author}

Zurita Mohd Yusoff,

Universiti Sultan Zainal Abidin,

Gong Badak Campus,

21300 Kuala Terengganu,

Malaysia.

Email: zurita@unisza.edu.my

\section{References}

Azra, A. (1994), Jaringan Ulama Timur Tengah Dengan Kepulauan Nusantara Abad XVII dan XVIII. Bandung: Penerbit Mizan.

Bakar, S. A. (1977), Institusi Shaykh Abdul Malik bin Abdullah: 1 Corak Pengajian Tradisi di Terengganu dan Kitab-kitab Padanya. (Master Thesis Persuratan Universiti Kebangsaan Malaysia).

Bakar, S. A. (1984), Shaykh Abdul Malik bin Abdullah dan Karangan-karangannya in Awang, M.S. \& Abdullah, M.Y. (ed.), PESAKA II (Monograf Lembaga Muzium Negeri Terengganu II). Lembaga Muzium Negeri Terengganu: Terengganu.

Bakar, S. A. (1985), Risalah Naql Shaykh Abdul Malik bin Abdullah Dengan Anotasi in Awang, M.S. \& Abdullah, M.Y. (ed.), PESAKA III (Monograf Lembaga Muzium Negeri Terengganu).

Bakar, S. A. (1989), "Sheikh Abdul Malik bin Abdullah (Tuk Pulau Manis)", WARISAN, (Jurnal Persatuan Sejarah Malaysia Cawangan Terenggganu). vol. 5, Terengganu: Persatuan Sejarah Malaysia Cawangan Terengganu.

Daud, I. C. (2012), Tokoh-tokoh Ulama' Semenanjung Melayu (1), Kelantan: Majlis Agama Islam dan Adat Istiadat Melayu Kelantan.

Hashim, J., \& Ali, A. K. (2019), Metode Penulisan Fiqh Oleh Nur al-Din al-Raniri dalam Kitab al-Sirat alMustaqim, Jurnal Syariah 17 (2), 267-298.

Malek, M. H. A., Wahid, N. A., Adam, F., Yunus, A. M., Yusoff, Z. M., \& Zin, E. I. E. W. (2019), Early Education of Ancient Terengganu Muslim's Scholars Before 19th Century, International Journal Of Academic Research In Business And Social Sciences, 9(11), pp. 771-777.

Mohd, H., Hashim, J., Mohd, Z. M., Khairuldin, W. M. K. F. W., Daud, K. A. (2017), The Contribution of Shaykh Abdul Qadir Bukit Bayas in Islamic Jurisprudence and Social Harmony, International Journal of Academic Research in Business and Social Sciences, 7(8), pp. 615-621.

Muhammad, A. K. (1996), Sejarah Penulisan Hukum Islam di Malaysia, Kuala Lumpur: Dewan Bahasa dan Pustaka.

Othman, M. R. (1998), The Role of Makka-Educated Malays In The Development of Early Islamic Scholarship And Education In Malaya, Jornal of Islamic Studies, 9(2), pp. 146-157.

Yusoff, Z. M. (2014), Kitab al-Kifayah Karangan Syeikh Abdul Malik bin Abdullah: Teks dan Analisis (Thesis PhD. Akademi Pengajian Islam Universiti Malaya, Kuala Lumpur). 